\begin{tabular}{|l|l|l||}
\hline \multicolumn{2}{|c|}{ PublisherInfo } \\
\hline \hline PublisherName & $:$ & BioMed Central \\
\hline \hline PublisherLocation & $:$ & London \\
\hline \hline PublisherImprintName & $:$ & BioMed Central \\
\hline \hline
\end{tabular}

\title{
Angioplasty versus thrombolysis for AMI
}

\begin{tabular}{|l|l|l||}
\hline \multicolumn{2}{|c||}{ ArticleInfo } \\
\hline \hline ArticleID & $:$ & 4107 \\
\hline \hline ArticleDOI & $:$ & $10.1186 /$ ccf-1999-2381 \\
\hline \hline ArticleCitationID & $:$ & 2381 \\
\hline \hline ArticleSequenceNumber & $:$ & 44 \\
\hline \hline ArticleCategory & $:$ & Paper Report \\
\hline \hline ArticleFirstPage & $:$ & 1 \\
\hline \hline ArticleLastPage & $:$ & 4 \\
\hline \hline & & RegistrationDate : 1999-12-1 \\
\hline ArticleHistory & $:$ & OnlineDate \\
\hline \hline ArticleCopyright & $:$ & Current Science Ltd1999-12-1 \\
\hline \hline ArticleGrants & $:$ & \\
\hline \hline ArticleContext & $:$ & 130541111 \\
\hline \hline
\end{tabular}




\section{Keywords}

Angioplasty, myocardial infarction, outcome, thrombolysis

\section{Comments}

This is an excellent study acknowledging the benefits of primary angioplasty in AMI. The importance of early restoration of coronary perfusion in preservation of LVEF is highlighted, so if current therapies are able to provide equivalent reperfusion rates to those seen in this study, then the beneficial effects on mortality should be paralleled. Obviously intracoronary stents and abciximab were not used in any of these patients, since the therapies were performed in the early 1990s, and so present day thrombolytic therapies may be as useful as mechanical techniques if reperfusion rates are now similar.

\section{Introduction}

The pros and cons of primary angioplasty compared with thrombolysis in acute myocardial infarction (AMI) continue to be debated. Weaver et alhave shown in pooled data of 10 randomised studies that early mortality, rates of stroke, and reinfarction are reduced following primary angioplasty compared to thrombolytic therapy. However, there is a paucity of long term survival data.

\section{Aims}

To compare long-term ( 5 year) morbidity and mortality data between primary angioplasty and thrombolysis following AMI.

\section{Methods}

Over a 3 year period (1990-93) 395 patients admitted with a diagnosis of AMI were randomised to receive either angioplasty or streptokinase. Follow-up angiography and radionuclide left ventricular 
ejection fraction (LVEF) measurements were performed on all patients. Thrombolysis in myocardial infarction (TIMI) grade 3 blood flow at angiography defined coronary patency. Follow-up data was collected in 1998 and involved reviewing medical records and contacting general practitioners.

\section{Results}

In total, 194 patients were randomised to primary angioplasty, of whom nine were treated conservatively and seven underwent immediate coronary artey bypass graft (CABG) following baseline angiography. Two hundred and one patients were randomised to streptokinase, but one died before receiving thrombolysis. In those who survived to follow-up angiography, patency was greater in the angioplasty group (90\% compared to $65 \%$ ). More patients in the streptokinase group had poor LVEF measurements (26\% compared to $14 \%$ ), and mortality due to cardiac causes was strongly associated with poor LVEF.In total, 74 patients died at follow up, $13 \%$ in the angioplasty group and 24\% in the streptokinase group. Non-fatal reinfarction was more common in the thrombolysis group (22\% vs $6 \%$ ) as were readmission rates for heart failure and ischaemia.

\section{Discussion}

Primary angioplasty results in lower long term mortality and reinfarction rates when contrasted with thrombolysis. Since there is a strong association between risk of death from cardiac causes and LVEF, it appears that the improved restoration of coronary perfusion to infarcted tissue by angioplasty, when compared to streptokinase, preserves myocardium and therefore LVEF. Presumably this improved LVEF in the angioplasty group prior to hospital discharge helps preserve long-term ventricular function, as readmission rates for heart failure were lower in this group. The authors highlight the limitations of their study and point out that advances in both mechanical and pharmacological reperfusion therapies have been made since 1993 (when this study was performed).

\section{Additional information}

An editorial accompanies this paper. 


\section{References}

1. Zijlstra F, Hoorntje JC, de Boer MJ, Reiffers S, Miedema K, Ottervanger JP, van'T Hof AWJ, Suryapranata H: Long-term benefit of primary angioplasty as compared with thrombolytic therapy for acute myocardial infarction. New Engl J Med. 1999, 341: 1413-1419.

This PDF file was created after publication. 